\section{A Study on Organizational Behaviour Dimensions That Support Successful Corporate Social Responsibility Initiatives}

\author{
Cristina Borca \\ Politehnica University of Timişoara, Romania \\ cristina_borca1@yahoo.com \\ Anca Drăghici \\ Politehnica University of Timişoara, Romania \\ anca.draghici@upt.ro \\ Sorin Suciu \\ Politehnica University of Timişoara, Romania \\ sorin.suciu@upt.ro
}

A Study on Organizational Behaviour Dimensions That Support Successful Corporate Social Responsibility Initiatives

\begin{abstract}
The main objective of the paper is to highlight some dimensions related to a responsible behaviour of organizations and the social perception of these aspects. The underlying idea has started from the need to identify the factors of organizational communication that can influence the social perception of the dimensions of the social responsibility of organizations. The proposed goals were achieved through the longitudinal analysis of statistical data, obtained from four opinion polls conducted during the period 2002-2015 within the organization chosen for the applied research. The dimensions considered for the investigation were image and reputation of the organization; the level of information; awareness of the contribution to environmental issues; aspects of crisis management (incident resolution); confidence in the way organizations work; customer satisfaction. All these aspects, characterized by appropriately defined indicators have been constituted as variables of the customer perception equation. Based on the evolution of the dimensions, various conclusions could be generated that highlight the customer's perception of the organization and its social responsibility behaviour. Based on these findings, it is necessary, as a first step in the development of corporate social responsibility strategies, to conduct a customer perception analysis to assess stakeholder support for a variety of social or environmental issues and ultimately substantiate their decision to engage in those initiatives that matter most to them (key initiatives).
\end{abstract}

Keywords - organizational behaviour, corporate social responsibility (CSR), organizational communication, customer perception, stakeholder, public perception

\section{Psynervia}

International Journal of Synergy and Research Vol. 7, 2018 pp. $5-13$ 
IJSR 7

\section{Introduction. The importance of social responsibility}

The European Commission (COM/2011/0681) mentions that corporate social responsibility (CSR) is equally important for companies, for the economy and society due to the following recognized benefits:

- for companies, it offers important benefits in areas such as risk management, cost savings, access to capital, customer relations, human resources management, and innovation management;

- at the level of the European Union's economy, it determines and constrains companies to be more sustainable and innovative, which contributes to the development of a more sustainable economy;

- for society, it provides a set of values on which a sustainable economic system can be built.

Organizations increasingly face challenges in assuming environmental, social and economic responsibility, challenges that will need to be integrated into the organizational sustainability strategy. As a result, firms will be increasingly concerned not only with getting higher profits at minimal costs, but also with the ethical way in which they are realized and distributed. Organizations' non-financial goals are already taken into account in many countries as part of the economic dimension of social responsibility and tend to become elements of competitiveness. In setting social responsibility strategies, companies should start from the real needs of communities and then define their goals in SMART objectives (Specific, Measurable, Attainable, Relevant, Timely) but also honest. The effects of strategic managerial balance, profit maximization strategies and social strategies (such as social responsibility), designed to support and develop local communities, protect the environment, improve living standards, will be reflected directly on market positioning of the company, creating a good image and implicitly increasing its economic and financial performance.

The extent to which an organization has defined and is involved in social responsibility activities to position itself on the market in front of its competitors may directly lead to an increase in its economic and financial performance (Du et al., 2007). However, the promotion of social programs should not only be done from the perspective of the image benefits they bring to an organization that develops and implements such programs. Between the declaration of intentions and the reporting of actions, between praise and ethics, the objective is to create positive effects at all levels and for all stakeholders (Debos, 2005). Based on these considerations, there is a clear need to create new models, methods and means of assessing perceptions of social responsibility activities in the new context of the dynamics of the external environment, society and organizations.

Three fundamental dimensions of CSR are defined according to their specific effects in the economic, social and environmental domains. These are known under the following acronyms: TBL or 3BT ("Triple Bottom Line") or 3P ("People, Planet, Profit"), defined for the first time in Elkington (1994). Over time, the number of dimensions associated with CSR has increased, cultural dimensions, values or ethics have been included, and the concept has evolved towards sustainable development and sustainability. For example, Werbach (2009) defines the concept of sustainability by expanding the number of dimensions to include cultural aspects. His perspective on sustainable business is based on four dimensions, which are briefly described below. 
- The social dimension involves behaviours that prove that people matter; it refers to: the eradication of poverty, violence, the application of the principles of equity, education, public health, employees' rights and human rights.

- The economic dimension contains aspects of how organizations achieve their economic goals. This dimension includes food, water, housing and comfort for people as well as making profits so that organizations can operate safely indefinitely.

- The cultural dimension implies the appreciation and protection of cultural diversity. It includes actions through which communities express their identity and cultivate their traditions from generation to generation.

- The environmental dimension is defined in relation to the role of the organization in protecting and restoring ecosystems. It includes actions and conditions related to: climate change, conservation of natural resources, the use of renewable resources and materials and the prevention/elimination of toxic waste.

The boundary between the concepts of CSR and sustainability is very fragile because both are very similar from many points of view. A recent approach introduced by Van Marrewijk and Werre (2003), which adds to the sustainability level a fourth "P" from the Principles to the three well-known "Profit, People, Planet". In addition, Van Marrewijk (2010) recommended that the two terms, "CSR" and "sustainability", to remain distinguished, being considered as:

- $\quad C S R$ refers to phenomena such as transparency, stakeholder dialogue and reporting;

- Sustainability focuses on values, value systems, environmental management, environment-friendly production systems, human capital management, etc.

In recent years, it can be noticed that more dimensions of corporate responsibility are described, like the ethical dimension. Ethics can be seen as diffused in the other dimensions, firstly because unethical conduct can have high costs, and secondly, because ethical codes provide the consistency and trust needed for profitable cooperation, and the trust of stakeholders is an essential component of any project (Newcombe, 2003). Also, values within the culture of the organization influence the perception of situations and problems.

By integrating all these dimensions into a graphical representation, the initial model can be extended to at least 6 dimensions to be taken into account when it comes to CSR or sustainability concepts.

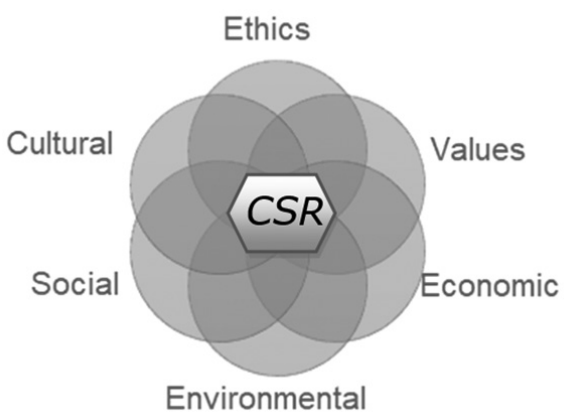

Figure 1. People-Planet-ProfitValues-Cultural-Ethics

Source: Authors' own study. 
IJSR 7

\subsection{The social responsibility perception}

A European Commission report entitled How Companies Influence Our Society: Citizens ' View (European Commission, 2013) investigates the views of citizens in seven European countries and Israel about their perceptions regarding companies' influence upon the society. The study achieved several objectives: the level of information, the perception of CSR companies' efforts, the perception of the global influence of the companies on society and the level of public interest in the subject of CSR. According to this study, IT companies are best perceived in their efforts to behave responsibly towards the community. Percentages of the population surveyed are: Malta (80\%), Romania (74\%), Lithuania (73\%), Bulgaria (66\%), Hungary (59\%), Slovakia (59\%) and Israel (58\%).

\subsection{The role of reputation in the perception of social responsibility}

A 2006 study on the influence of an organization's reputation on social responsibility perceptions (Yoon et al., 2006) shows that firms with a good reputation are perceived as credible, with an enhanced impact of social responsibility actions, while firms with poor reputations have mitigated or even reversed effects. Interestingly, companies with "neutral" reputation are advantaged in comparison with those with a positive reputation in harvesting social benefits (Strahilevitz, 2003).

According to Yoon et al. (2006), it was found that social responsibility activities can turn against companies when customers find out that the budget allocated for campaign advertising exceeds the financial contributions of social responsibility actions. It is shown in the study that when customers learned that the budget allocated for advertising exceeded the budget allocated for the CSR campaign, they rated the company negatively. In this case, the donation of USD 2.1 million for a social cause, for which advertising costs were USD 18.3 million, was perceived negatively, worse than if it had not been done. Good reputation, built on principles of transparency, is increasingly becoming a target for organizations. The influence of reputation is reflected on how companies are perceived, which directly affects business (Knowles, 2014).

Based on these findings, it is necessary, as the first step in the development of CSR strategies, to conduct a customer perception analysis to assess stakeholder support for a variety of social or environmental issues and ultimately substantiate their decision to engage in those initiatives that matter most to them (key initiatives). Therefore, stakeholders expect organizations to address those social or environmental issues that are relevant to core business. Thus, the effects of organizational involvement in the community means taking into consideration all stakeholders and developing a strategy of social involvement that integrates in the medium and long term in the organization development strategy (Cristache, 2006). Based on the problematic and phenomenological considerations described above, the objectives of the research have been clarified and formulated, as well as the way to achieve them.

\subsection{The role of corporate communication in the perception of social responsibility}

The proposed innovative approach can be considered both a diagnosis and a prediction tool of customer and organization behaviour and is based on relevant dimensions for describing the interrelationship of CSR - Organisational Communication - Stakeholder Perception. 
The challenge is to identify the factors that can influence the perception of the public about the dimensions of the social responsibility of organizations. Several aspects must be taken into account, for example:

- the level of information;

- $\quad$ image and reputation of the organization;

- $\quad$ aspects of crisis management (incident resolution);

- confidence in the way organizations work;

- customer satisfaction;

- awareness of the contribution to environmental issues.

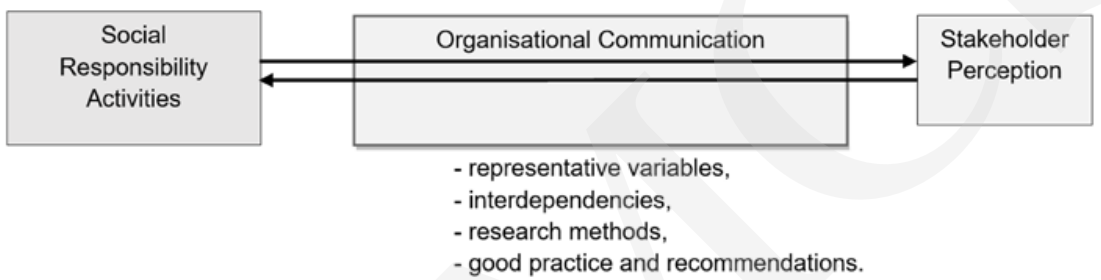

Source: Authors'own study.

The proposed goal was achieved based on the conclusions of the longitudinal analysis of statistical data obtained from opinion polls conducted during the period 2002-2015 within the organization chosen for the applied research - the case of a large water utility company, located in Timişoara, Romania, west country side (www.aquatim. ro/posmediu/). The study case, generically called "the water sector", is one of the most representative for this research because of the social and environmental dimensions that it performs. Based on the evolution of the studied dimensions, various conclusions could be generated that highlight the customer's perception of the organization and its social responsibility behaviour.

\section{The role of corporate communication in the perception of the CSR environmental dimension}

\subsection{Methodological part}

The purpose of the study is to highlight some dimensions related to a responsible behaviour of organizations and the public perception of these aspects. More exactly, the main goal is to evaluate the public's perception regarding the environmental dimension carried out by a water company located in the western part of Romania.

In order to evaluate "Environmental Awareness", statistical data of some opinion polls conducted for 2012 and 2015 was analysed: Initial Opinion Survey of the Population in Timis County (2012) and Final Opinion Survey of the Population in Timis County (2015). For 2002 and 2011, a research was conducted at the water company level. The results of the survey, from 2005 to 2015 , showed that a total of 1,743 subjects responded to the questionnaire. Applied research aimed at the longitudinal analysis of specific indicators based on data obtained from the Aquatim SA Timişoara company. This data are answers
A Study on Organizational Behaviour Dimensions That Support Successful Corporate Social Responsibility Initiatives

Figure 2. The interrelation CSR - Communication Perception 


\section{IJSR}

\section{7}

Figure 3.

Response distribution: "It is treated not to affect the environment and then evacuated into the nature"

Figure 4.

Distribution of positive opinion on payment for wastewater treatment regarding the need to treat wastewater before discharging into rivers (emissaries). Also, it was considered into an equation the acceptance of the treatment costs included in the structure of service tariffs.

Investigating this dimension provides a first overview of the impact of organizational communication on social responsibility policy (with reference to policy, tactics, actions on wastewater treatment) for the water company in Timişoara. So, the dimension "Environmental Awareness" is described by two variables according to the relationship:

Environmental awareness $=f$ (necessity of waste water treatment, payment acceptance for wastewater treatment services)

As can be seen in Figure 3, over half of the respondents stated in 2005 that the wastewater that reaches the sewerage network is treated in order not to affect the environment and then evacuated in nature. At the level of 2015 , it is noted that the percentage of responses increased significantly to over $80 \%$.

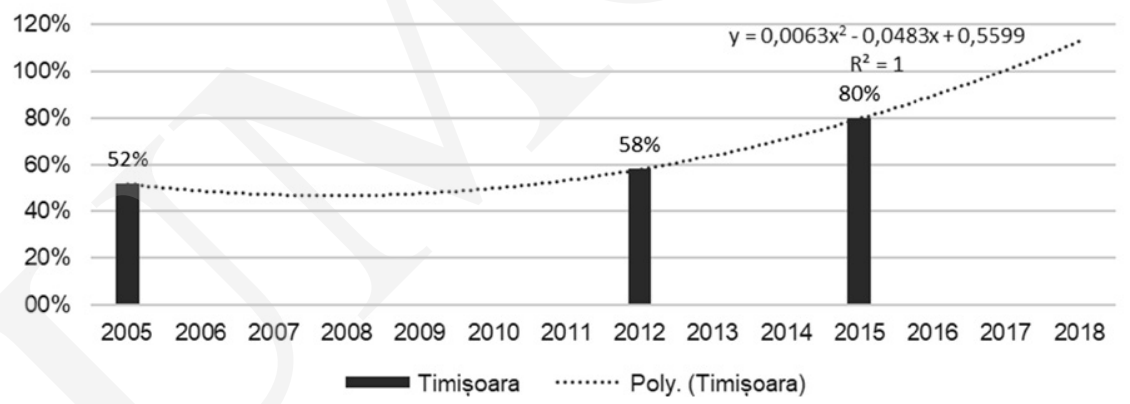

Source: Bunget (2018).

The rising trend associated with the respondents'/customers' answers to this question reflects the fact that, during the analysis period, organizational communication (strategies, policies, tactics) was getting better and more appropriate for customers. Thus, the data analysis presented in Figure 3 highlighted that customers have a good perception of the wastewater treatment (associated with sustainability and social responsibility of the company) due to the communication tactics used, and the rigors imposed by the projects (in the field of communication and image concerns).

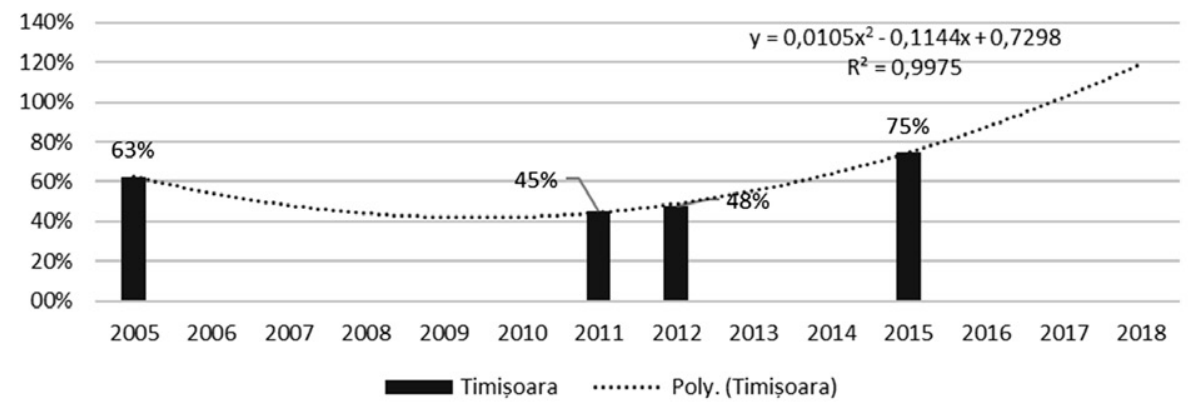

Source: Bunget (2018). 
In 2005 , more than $60 \%$ of those surveyed in Timişoara expressed their positive opinion on the payment for wastewater transportation and treatment services (Figure 4). The percentage increased to over $70 \%$ in the year 2015. In this case, the trend curve shows the mood and awareness of respondents/clients of actions aimed at supporting environmental quality and social responsibility actions, as a result, the positive impact of organizational communication efforts has been noted. The trend curve is increasing, demonstrating an increase in organizational communication efforts directed towards a positive perception of supporting environmental quality activities and social responsibility actions.

The findings of the "Environmental Awareness" research have highlighted the fact that there is a category of customers with a poor perception of environmental issues and the company's efforts to protect the environment. That is why it is necessary to intensify communication efforts to increase perception in this area. Thus, the communication process needs to be improved, redefined so these differences will be eliminated in the future.

\begin{tabular}{lll}
\hline Customers/respondents & $\begin{array}{c}\text { Wastewater is treated in order not } \\
\text { to affect the environment and then } \\
\text { evacuated in nature }\end{array}$ & $\begin{array}{c}\text { "I accept payment for wastewater } \\
\text { treatment" }\end{array}$ \\
\hline Timişoara & Well-informed customers & Customers accept payment \\
\hline $2005-2015$ trend & Strongly increased (from 50\% to 80\%) & Increased (from 63\% to 75\%) \\
\hline
\end{tabular}

Source: Bunget (2018).

\section{Study limitations}

The number of the existing data provided by the company constitutes the limit. The research was based on the data analysis of responses to three or four opinion polls conducted between 2005 and 2015, repeat times vary from 1 year to 6 years. The opinion polls were conducted by phone, so only those who were contacted by phone were included in the sample. What is more, in different opinion polls, different people were interviewed.

\section{Directions for further research}

Building new evaluation public tools regarding other environmental behaviour such as water consumption vs. water resources, climate changes vs. adaptation, or reducing consumption vs. resource depletion, etc.

\section{Conclusions}

Defined as "meeting the needs of the current generation without compromising the ability of future generations to meet their own needs" (WCED, 1987), social responsibility has become a real need for society and individuals. Public concern about environmental issues has increased exponentially. The public has become increasingly sensitive to issues related to waste management, recycling, sustainable development, clean production, CSR or the product life cycle.

Communicating with the public has a key role in making sustainable development understandable. Dialogue, communication and stakeholder involvement are the engine
A Study on Organizational Behaviour Dimensions That Support Successful Corporate Social Responsibility Initiatives

Table 1. Centralizing the responses to the "Environmental Awareness" based on statistical data processing 
IJSR 7

for awareness and action to build a sustainable society by influencing the individual and collective values of stakeholders. Effective communication is a fundamental part of the business environment because it provides an essential link between people and supports relationships between them. The lack of effective communication in a company reduces productivity and generates barriers to business performance. Communicating social responsibility must go beyond the boundaries of specialized compartments and become the responsibility of the entire organization. All departments of the organization, human resources management, public relations, marketing, production, finance, etc. must communicate the involvement of the organization in actions, projects and CSR initiatives (Benn et al., 2014; Sueldo, 2016).

\section{References}

Benn, S., Dunphy, D., and Griffiths, A. (2014), Organizational Change for Corporate Sustainability, Routledge, Abingdon-New York.

Bunget, C. (2018), The role of corporate communication in the perception of social responsibility's dimensions. Doctoral thesis, Politehnica University of Timişoara, Doctoral School of Engineering.

$\operatorname{COM}(2001) 366$ - Not published in the Official Journal. Green Paper (2001) - Promoting a European framework for Corporate Social Responsibility COM/2011/0681, available at: http://ec.europa. eu/growth/industry/corporate-social-responsibility_en (accessed: 10 March 2018).

Cristache, N. (2006), "The role of public relations in social responsibility of Romanian enterprises", Economics and Applied Informatics, no. 1, pp. 15-18.

Debos, F. (2005), L'impact de la dimension ethique dans la strategie de communication de l'entreprise : la necessite d'une communication « responsable », Communication et organisation, vol. 26, pp. 92-103.

Du, S., Bhattacharya, C.B., and Sankar, S. (2007), "Reaping relational rewards from corporate social responsibility: The role of competitive positioning", International Journal of Research in Marketing, vol. 24, no. 3, pp. 224-241.

Elkington, J. (1994), "Towards the sustainable corporation: Win-win-win business strategies for sustainable development", California Management Review, vol. 36, no. 2, pp. 90-100.

European Commission (2013), Public Opinion in the European Union. Standard Eurobarometer Survey 363. How Companies Influence Our Society: Citizens' View, available at: http:// ec.europa.eu/commfrontoffice/publicopinion/flash/fl_363_en.pdf(accessed: 10 March 2018).

Initial Opinion Survey of the Population in Timis County (2012), available at: http://www.aquatim. ro/uploads/files/Studiu\%20de\%20opinie\%20clienti\%20Aquatim_03\%20iulie\%202012.pdf (accessed: 10 April 2018).

Final Opinion Survey of the Population in Timis County (2015), available at: http://www.aquatim.ro/ posmediu/wp-content/uploads/2013/03/Aquatim_Studiu-de-opinie-clienti-2015-versus-2012 POS-Mediu.pdf (accessed: 10 April 2018).

Knowles, V. (2014), "Ever wondered what your peers spend on CSR reporting?", 2 degrees, 16 July, available at: https://www.2degreesnetwork.com/groups/2degrees-community/resources/ ever-wondered-what-your-peers-spend-csr-reporting/ (accessed: 10 March 2018).

Newcombe, R. (2003), "From client to project stakeholders: A stakeholder mapping approach", Construction Management and Economics, vol. 21, no. 8, pp. 841-848.

Strahilevitz, M. (2003), "The effects of prior impressions of a firm's ethics on the success of a causerelated marketing campaign: Do the good look better while the bad look worse?", Journal of Nonprofit \& Public Sector Marketing, vol. 11, no. 1, pp. 77-92. 
Sueldo, M. (2016), "The impact of integrated organizational communication on organizational sustainability”, Management of Organizations: Systematic Research, vol. 75, pp. 121-140.

Van Marrewijk, M. (2010), "Strategic orientations: Multiple ways for implementing sustainable performance", Technology and Investment, vol. 1, no. 2, pp. 85-96.

Van Marrewijk, M., and Werre, M. (2003), "Multiple levels of corporate sustainability", Journal of Business Ethics, vol. 44, no. 2-3, pp. 107-119.

WCED (1987), Our Common Future: Report of the World Commission on Environment and Development, Oxford University Press, Oxford.

Werbach, A. (2009), Strategy for Sustainability: A Business Manifesto, Harvard Business School Publishing, Boston, MA.

Yoon, Y., Gürhan-Canli, Z., and Schwarz, N. (2006), "The effect of corporate social responsibility (CSR) activities on companies with bad reputations", Journal of Consumer Psychology, vol. 16 , no. 4, pp. 377-390.
A Study on Organizational Behaviour Dimensions That Support Successful Corporate Social Responsibility Initiatives 